\title{
Effect of processing on the nutritive value of cereals in animal feeds
}

\author{
By A. W. A. Burt, Burt Research Limited, 23 Stow Road, Kimbolton, Huntingdon \\ $P E$ 工 8 oHU
}

Since cereals provide much of the digestible energy and considerable amounts of the protein in feeds for livestock, effects of the processing to which they are subjected are of considerable practical significance. In most developed countries, a substantial proportion of the total supply of cereals is used for feeding livestock. In the United Kingdom, the Home Grown Cereals Authority have estimated that of the 22 million tons of imported and home-produced wheat, barley, oats and maize available in $1969-70$, over $\mathrm{r}_{3}$ million tons were used in animal feed (Sturgess \& Reeves, I972).

Unlike human foods, economic considerations are paramount and organoleptic factors are of relatively little importance in processing cereals for livestock. Processing costs can only be incurred if they are accompanied by a more than commensurate increase in the value of the cereal. In consequence, most of the cereals used are subjected to relatively simple processes. Recently, however, there has been increasing interest in more sophisticated processing techniques, supported by the increasing economic value of cereals and animal products and the increasing size of unit in animal production enterprises.

The following factors have to be considered in any study of processing ( $\mathrm{I}$ ) species of cereal and variation within the species; (2) the particular process or processes applied; (3) species and class of animal fed; (4) relative place of the cereal processed with respect to the rest of the diet of the animal.

Apart from the problems posed by the variation in the reaction of the animal, which is often not sufficiently well-defined to allow clearcut definitions of requirements for processing, there can be appreciable differences in the physico-chemical properties within each species of cereal grain, which can interact with the process. Furthermore, the processes are often poorly controlled and their effects upon the physical and chemical properties of the grain are not completely understood. It is therefore not surprising that there is often considerable contradiction in the results relating to the application of a particular process to a particular cereal fed to a given category of animal.

Four processes are considered in this paper. 
I. Grinding, rolling or cracking to break down the grain and expose interior surfaces to the action of digestive and microbial enzymes

Of these, grinding is the most common and is often followed by pelleting after admixture of the ground cereal with the other constituents of the concentrate. Although the process of grinding is often defined in terms of the size of the holes in the screen through which the material is ground, it is well recognized that the resulting distribution of particle sizes in the ground material arising from a given cereal may vary considerably. It is affected, amongst other things, by moisture content, rate of feed to the mill, speed of rotation of the beaters and other design characteristics of the mill. Rolling is also subject to considerable variations in its effects. Generally these processes modify particle size or shape, or both, without inducing chemical changes in the cereal.

\section{Pelleting of the ground material, using a ring-roll press or other pelleting device with or without previous treatment with steam, i.e. 'hot' or 'cold' pelleting}

This process is usually applied to the whole of the concentrate mixture which includes a ground cereal or cereais among other components. Considerable variation is possible in the amounts of heat and moisture applied to the meal mixture before pelleting, and in the amount of heat generated when the meal is extruded through the pelleting die because of substantial variation in the mechanical nature of feed materials. Temperature levels reached in the die are not generally known, but estimates of $120^{\circ}-260^{\circ}$ have been made. Pelleting may therefore cause some further breakdown in particle size, and some gelatinization of starch may occur at the surface of pellets at low throughputs and high temperatures, but the extent of these effects is generally assumed to be minor.

\section{Heat treatments}

A variety of these have been used (Armstrong, 1972) at least experimentally. In the USA, steam-flaking treatments have been used which expose the grain to steam at atmospheric pressure for $8-25$ min or to higher pressures for shorter periods before rolling. Cooking-extrusion processes have been used in which water is added to ground cereals and the mixture is steam-heated before extrusion at high temperatures and pressures resulting in appreciable gelatinization of the cereal starch (Colenbrander, Bartley, Morrill, Deyoe \& Pfost, I967).

Micronization is a more recent development, in which whole cereal grains at normal moisture content, are exposed to infrared irradiation generated by special ceramics heated by gas or electricity to a predetermined temperature. Exposure times of around $\mathrm{I}$ min give rise to appreciable internal heating within the grain which 'pops' a small proportion of the cereal. The heat-treated grains are rolled immediately to thin flakes.

Neither the steam treatment before flaking nor micronization bring about extensive gelatinization or notably increase the quantity of readily available starch. These are enhanced considerably by the physical action of rolling the heated material 
immediately to thin flakes (Frederick, Theurer \& Hale, 1968; T. L. J. Lawrence, personal communication).

\section{Water treatments}

These include (a) harvesting unripe grain; (b) harvesting ripe but moist grain. Unripe and ripe, moist grain may be subsequently stored under anaerobic conditions in sealed storage or in the presence of air after the addition of propionic acid to prevent spoilage by mould growth. Such grains are usually rolled before feeding. (c) Reconstitution-water is applied to dry maize or sorghum grain to increase its moisture content to around $30 \%$ before anaerobic storage for at least $2 \mathrm{x} \mathrm{d}$. The grain is then ground or rolled before feeding. The efficiency of this process, at least in improving the in vitro digestibility of sorghum, appears to depend upon the moisture content and time and temperature of storage (Neuhaus \& Totusek, 197x). Since reconstitution after grinding appears to be without effect, the process may depend upon grain modification by microbial or enzymic activity, or by both.

\section{Ruminants}

Effects of processing grain for fattening cattle and sheep have been recently reviewed by Armstrong (1972), and this section will therefore be more concerned with the response of the dairy cow. Although it is generally accepted that grinding, rolling or breaking grain is usually necessary for its optimum utilization by ruminants, whole grain may often be given satisfactorily to mature sheep, whereas young cattle utilize whole grain relatively more effectively than mature cattle (see Armstrong, 1972; Nicholson, Gorrill \& Burgess, 1971). These differences appear to be related to the extent to which the grain is masticated. For maize it has recently been suggested that mature cattle may make effective use of the whole grain in some instances. Adeeb, Wilson \& Campling (r97r) reported that mature cows digested whole maize stored moist after treatment with propionic acid more effectively than coarsely ground, dry maize and concluded that the optimum digestibility of dry maize was achieved by grinding it to a modulus of fineness between 4.8 and 3.0 . Whole maize grain has also given better results than crimped maize in high-grain rations for fattening cattle, but crimped maize was, if anything, superior when the diet contained appreciable amounts of maize silage (Vance, Preston, Klosterman \& Cahill, 1972).

There appear to be few studies of the effects of fineness of grinding of cereals or concentrate-meal mixtures upon the productive efficiency of the lactating cow. Holm, Saue, Ulvesli \& Vadla (I96r) reported that coarse or fine grinding of the same meal mixtures containing substantial proportions of mixed cereals had no effect upon milk production or milk quality.

One of the most interesting aspects of processing grain for ruminants lies in its possible effect upon the sites of absorption of nutrients and the pattern of energy-yielding metabolites absorbed. A proportion of ground maize escapes breakdown by rumen micro-organisms, and diets containing a substantial proportion of this feed may result in around $20 \%$ of dietary $\alpha$-linked glucose polymer $32(1) 3$ 
passing to the duodenum, whereas flaked maize is largely digested in the reticulorumen and little $\alpha$-linked glucose polymer reaches the duodenum (Armstrong \& Beever, I969; Beever, Coelho da Silva \& Armstrong, 1970). Ground barley gives results somewhat similar to those for flaked maize (Ørskov, Fraser \& Kay, 1969). These changes result in practically no change in the total digestibility of dietary carbohydrate. The extent to which carbohydrate which escapes digestion in the rumen is absorbed as glucose, when enhanced productivity would be expected, as opposed to being fermented to volatile fatty acids (VFA) lower down the tract, is not clear (Ørskov et al. 1969).

If heat-processing of grain results in substantial alteration in the pattern of VFA production in the reticulo-rumen, there may be substantial alterations in the amount of bacterial protein and organic matter reaching the duodenum. Ishaque, Thomas \& Rook (I97I) and Jackson, Rook \& Towers (I97I) have demonstrated that VFA production patterns characterized by high proportions of propionic acid can be associated with increased flow of organic matter and bacterial protein nitrogen to the duodenum and increased availability of protein $\mathrm{N}$ to the animal. However, the same authors showed that this type of rumen fermentation is not consistent in sheep receiving a standard diet of ground hay, barley and flaked maize, as another type of fermentation characterized by high proportions of butyric acid was almost equally common, and was associated with higher concentrations of rumen ammonia and much lower rates of flow of organic matter and $\mathrm{N}$ to the duodenum. Substantial differences in the fermentation pattern observed with the same diet must therefore be attributed to individual animal effects and other unknown factors, probably acting through amendments to the make-up of the microbial population of the reticulo-rumen.

Fermentation pattern may also be modified by the feeding regimen used with diets of constant composition, for Eadie, Hyldegaard-Jensen, Mann, Reid \& Whitelaw (I970) showed that the fermentation pattern characterized by a high proportion of propionic acid in steers fed on barley cubes $a d$ lib. was amended to one characterized by a high proportion of butyric acid when the intake of barley cubes was restricted to $80 \%$ of ad lib. intake. These two examples show that, even using diets regarded as relatively extreme compared with normal practice, systems of feeding and unknown factors can profoundly modify rumen fermentation patterns.

It is therefore not surprising that the response of the ruminant, particularly the dairy cow, to heat-processed cereals, is not notably predictable and most processes have been associated with practical animal responses which may be zero, marginal or major. For example, Balch, Broster, Rook \& Tuck (1965) gave ground maize or flaked maize as $276 \mathrm{~g} / \mathrm{kg}$ of a diet providing $600 \mathrm{~g}$ concentrates and $400 \mathrm{~g}$ long or ground hay $/ \mathrm{kg}$ diet to lactating dairy heifers. In the presence of long hay, substitution of flaked maize for ground maize was without effect upon milk production or composition. Substitution of ground hay for long hay resulted in a substantial depression in milk fat content and a further depression then occurred when flaked maize was substituted for ground maize. In short, these animals were already in a critical condition with respect to the production of milk fat before the substitution of flaked maize for ground maize had any appreciable effect. 
Marginal effects upon milk production of subjecting barley to a cooking and extrusion process which gelatinized around $25 \%$ of the starch have been recorded (Burt, Dunton, Atkinson, Bush, Thomson, Durran, Aspinall \& Whiteley, 1973). When this material replaced equal amounts of similar untreated ground barley in pelleted concentrate mixtures fed to dairy cows, there was a slight but significant linear increase in milk yield as the level of substitution was increased from I 80 to $800 \mathrm{~g} / \mathrm{kg}$ of the concentrate mixture. At the highest level of substitution, the increase in milk yield was only $3 \%$, and only at this high level of substitution was there any adverse effect upon milk fat content, and a slight increase in the solidsnot-fat content of the milk. These slight changes were probably due to somewhat more rapid breakdown in the reticulo-rumen of the carbohydrate in the treated barley with some slight effects upon the pattern of VFA production.

Though mild heat-treatments are usually without effect upon the apparent digestibility of cereals for ruminants (Armstrong, 1972), except possibly improving the digestibility of sorghum, severe treatments such as cooking a mixture of steamrolled barley and wheat bran at $90^{\circ}$ for $\mathrm{I} \mathrm{h}$ or treatments which gelatinize almost all the starch in the grain have been reported to adversely affect digestibility (Hashizume, Tanabe, Haryu \& Itoh, I967; Mudd \& Perry, 1969).

Studies of the response to pelleting have usually involved either the whole diet or the whole of the concentrate component. Holm et al. (196I) have compared pelleted with finely ground or coarsely ground concentrate mixtures and found that pelleting tended to increase milk production and slightly reduce milk-fat content.

One of the few studies on the effects of pelleting the cereal portion of the diet of dairy cows was reported by Hawkins, Parr \& Little (1963), and their results illustrate the complexities of the responses which can occur. Maize or oats were offered ground or pelleted as $700 \mathrm{~g} / \mathrm{kg}$ of the concentrate mixture with $300 \mathrm{~g}$ cottonseed meal $/ \mathrm{kg}$. These four concentrate mixtures were then given as 500 or $700 \mathrm{~g} / \mathrm{kg}$ of the total diet, with lucerne hay providing the remainder. There was little effect upon milk yield. Milk-fat content was depressed by pelleted as opposed to ground maize and this depression was appreciably greater with the low-roughage ration than with the high-roughage ration. With oats, however, pelleting tended to increase milk-fat content at either roughage level. The authors attributed as least part of these responses to changes in rumen fermentation, where oats were associated with higher proportions of butyric acid than was maize, and pelleting increased the proportions of butyric and propionic acids. They also noted that the ground cereals were conditioned to temperatures of $66^{\circ}$ for maize and $76^{\circ}$ for oats before pelleting, but that this temperature difference had practically doubled after extrusion, presumably as a result of the greater mechanical work involved in pelleting the relatively fibrous ground oats. In the light of this paper, it is important to note that most of the observations on depressed milk-fat content after pelleting have been associated with dietary inclusions of maize and with relatively high ratios of concentrates: roughage in the ration (Bishop, Loosli, Trimberger \& Turk, ${ }^{2} 9_{3}$ ).

Reconstitution of grain has been extensively studied as a means of improving the utilization of sorghum in beef 'feedlots' in Texas. Sorghum which has been 
reconstituted, or harvested early at high moisture contents and then ground, has been observed to often improve the responses in efficiency of food conversion in cattle, compared with ground dry sorghum (Riggs \& McGinty, 1970). However, it must be remembered that there is a substantial variation in the digestibility of different types of sorghum (McGinty \& Riggs, Ig68) and that some of the effects observed have been associated with improvement in the digestibility of relatively poor sorghums, possibly by modifying interference with digestion by tannin-like materials which are present in the brown 'testa' adjacent to the endosperm in certain types of sorghum. Reconstituted and ground sorghum has been shown in some instances, like the flaking of maize, to reduce the proportion of dietary carbohydrate reaching the abomasum (McNeill, Potter \& Riggs, I97I) and to increase the proportion of bacterial or dietary protein $\mathrm{N}$ reaching the same location (Potter, McNeill \& Riggs, I97I). Steam-flaked, but not micronized, sorghum gave similar effects in the same experiments. There appear to be very few observations on the effect of reconstitution upon the dairy cow, however, there are suggestions of depression in milk-fat content, but the details of the experiment have not been published (Helm, 1970, quoted by Helm, Lane \& Leighton, 1972).

Wet-stored maize or barley, ground, or more usually rolled, before feeding has given satisfactory results in feeding dairy cows, particularly when treated with propionic acid. Forsyth, Mowat \& Stone (I972) reported slight non-significant increases in milk yield and decreases in milk-fat content when ground, high-moisture maize that had been stored with the addition of $\mathrm{I} \cdot 5 \%$ propionic acid replaced ground dry maize in the diet and attributed part of this effect to the addition of propionic acid, and Jones, Donefer \& Elliott (1970) observed some marginal increases in milkprotein content when maize was treated with propionic acid.

\section{Pigs}

Lawrence (1972a, b, $c$ ) has reviewed the processing of cereals for pigs. Grinding or rolling to thin flakes is generally considered to be essential for optimum digestion, and there is evidence of increasing digestibility with increasing fineness of grinding. However, finely ground meals, particularly maize, are associated with increased incidence of ulceration of the oesophageal region of the stomach (see Lawrence, 1972a). Stomach contents of pigs given these ulcerogenic diets are usually much more fluid, their $\mathrm{pH}$ is higher, and the rate of passage of food through the gut is slower (see Lawrence, $1972 a$ ). It has been suggested that the fluid nature of the stomach contents allows pepsin and acid to be transferred to the relatively unprotected oesophageal region more easily (Maxwell, Reimann, Hoekstra, Kowalczyk, Benevenga $\&$ Grummer, $197^{\circ}$ ) or that regurgitation of duodenal contents may occur (Reed \& Kidder, I970).

Effects of pelleting have been reviewed by Vanschoubroek, Coucke \& Van Spaendonck (197I), who summarized 117 experiments which showed that on average pelleting improved growth rate by $6.6 \%$ and food conversion by $7.9 \%$. Although improvements in digestibility were reported in some experiments, a major portion of the effect may have been due to reduced food wastage. There is some 
evidence that pelleting, particularly of finely ground meals, may increase the incidence of gastric ulceration (Flatlandsmo \& Slagsvold, r971). 'Cold' pelleting may be superior to 'hot' pelleting because of adverse effects of the latter upon digestibility (Lawrence, $197 \mathrm{I}$ ).

The flaking of cereals may marginally improve digestible energy by around $3 \%$ if the flakes are ground before feeding, but $\mathrm{N}$ balance is depressed, suggesting that the process has adverse effects upon protein quality (Lawrence, 1972c).

No positive response to treatments which result in a high degree of starch gelatinization appears to occur (Riker, Perry, Pickett \& Curtin, r 967 ) and such treatments may also increase the incidence of gastric ulcers.

Micronization appears to improve food conversion with barley and more particularly maize, but gives no response with wheat, compared to the ground cereal (Lawrence, 1972c).

Moist stored barley has been found to be inferior to dry barley in some experiments (cf. Livingston \& Livingston, I970; Perez-Aleman, Dempster, English $\&$ Topps, 1971) but not in others (Lawrence, r971; Livingston, Denerley, Stewart \& Elsley, 197I). Experiments on this subject have covered a number of variants of storage procedures and subsequent treatments, and the picture is not yet clear. However, acid-treated moist barley may be superior to anaerobically stored moist barley and the organic acids used to preserve the former may contribute to its nutritive value (see Lawrence, $1972 c$ ).

\section{Poultry}

Processing cereals and diets for poultry has been discussed by, among others, Calet (1965), Bayley, Summers \& Slinger (1968), Vohra (1972), and a full discussion is not attempted here.

\section{Assessment of the physical and chemical effects of processing}

The processing techniques commonly used alter the particle size and shape of the cereal and may affect the physico-chemical nature of its components. Often, neither class of effect is adequately described by the techniques at present used. Armstrong (1972) has listed some of the in vitro methods used to indicate the changes in the availability of starch in cereals before and after processing; the assessment of degree of gelatinization of starch by birefringence is well known.

These techniques measure some of the effects of processing, but are probably not sufficiently related to animal performance to be other than somewhat crude indications of process efficiency. There is a need for more detailed descriptions of the physical and chemical changes induced, particularly by some of the newer processes, coupled with studies on the effects of systematic variations in process conditions, to provide a firm base for animal experiment.

When processing affects particle size, modulus of fineness and modulus of uniformity have often been used as measures of the geometric mean of particle diameter and the distribution of particle size. More recently, when ground particles are being considered, Waldo, Smith, Cox, Weinland \& Lucas (I97I) have pointed out that 
the size distributions of these should be adequately described by the mean and standard deviation of the logarithm of particle size. These authors also point out that adequate detailed studies of the statistical relevance of this approach to ground concentrate ingredients are almost completely lacking. A further difficulty with sieving techniques for determination of distribution of particle size is their failure to provide relevant information about the somewhat irregular particles which arise from rolling or flaking cereals. In this instance flake thickness may be far more relevant than the results of sieving tests (Lawrence, $1972 c$ ).

Although most of this paper is concerned with effects of processing upon the carbohydrate constituents of cereals, it must be remembered that heat-processing particularly can modify the solubility of protein and may affect vitamin content. Some reference to the effects upon protein has already been made. Possible effects of the normal feed manufacturing process upon vitamin destruction have been considered by Pickford ( 1968 ) and Clement ( 1966 ), and the effects of more severe treatments have received some attention in the studies of Zimmerman \& Wostmann (1963). There appears to be little information about the effects of some of the newer processing techniques upon vitamin content, nor is there complete understanding of the possible effects of pelleting (Pickford, r968).

Many questions remain unanswered about the effects of processing cereals and other animal feed components upon their nutritive value. There is a requirement not only for more precise descriptions of the processes applied to such materials and for better process control, but also for more detailed study of the physicochemical changes brought about by processing and for more understanding of the relevance of such changes to animal nutrition.

\section{REFERENCES}

Adeeb, N. N., Wilson, G. F. \& Campling, R. C. (1971). Anim. Prod. 13, 39 r.

Armstrong, D. G. (1972). In Cereal Processing \& Digestion p. 9. London: US Feed Grains Council.

Armstrong, D. G. \& Beever, D. E. (1969). Proc. Nutr. Soc. 28, 121.

Balch, C. C., Broster, W. H., Rook, J. A. F. \& Tuck, V. J. (1965). F. Dairy. Res. 32, I.

Bayley, H. S., Summers, J. D. \& Slinger, S. J. (1968). Poult. Sci. 47, 93 I.

Beever, D. E., Coelho da Silva, J. F. \& Armstrong, D. G. (1970). Proc. Nutr. Soc. 29, 43 A.

Bishop, S. E., Loosli, J. K., Trimberger, G. W. \& Turk, K. L. (1963). F. Dairy Sci. 46, 22.

Burt, A. W. A., Dunton, C. R., Atkinson, W., Bush, T. J., Thomson, I., Durran, A. A., Aspinall, L. J. \& Whiteley, K. B. (1973). Anim. Prod. (In the Press.)

Calet, C. (1965). Whld Poult. Sci. F. 21, 23.

Clement, G. H. (1966). Proc. Nutr. Soc. 25, 3 I.

Colenbrander, V. F., Bartley, E. E., Morrill, J. L., Deyoe, C. W. \& Pfost, H. B. (1967). F. Dairy Sci. 50, 1966.

Eadie, J. M., Hyldegaard-Jensen, J., Mann, S. O., Reid, R. S. \& Whitelaw, F. G. (197o). Br. F. Nutr. 24, 157.

Flatlandsmo, K. \& Slagsvold, P. J. (1971). F. Anim. Sci. 33, 1263.

Forsyth, J. G., Mowat, D. N. \& Stone, J. B. (1972). Can. F. Anim. Sci. 52, 73.

Frederick, H. M., Theurer, B. \& Hale, W. H. (1968). F. Anim. Sci. 27, r т 10.

Hashizume, T., Tanabe, S., Haryu, T. \& Itoh, M. (1967). Bull. natn. Inst. Anim. Ind., Japan Summaries I4, 9, 10-II.

Hawkins, G. E., Parr, G. E. \& Little, W. O. (1963). F. Dairy Sci. 46, 1073.

Helm, R. E., Lane, G. T. \& Leighton, R. E. (1972). F. Dairy Sci. 55, 979.

Holm, H., Saue, O., Ulvesli, O. \& Vadla, E. (I 96I). Norg. LandbrHøisk. Beretn. Foringsfors. no. I02.

Ishaque, M., Thomas, P. C. \& Rook, J. A. F. (I97 I). Nature, Lond. 23I, 253.

Jackson, P., Rook, J. A. F. \& Towers, K. G. (197I). Proc. Nutr. Soc. 30, IA. 
Jones, G. M., Donefer, E. \& Elliott, J. I. (r970). Can. F. Anim. Sci. 5o, 483 .

Lawrence, T. L. J. (I971). F. Sci. Fd Agric. 22, 403 .

Lawrence, T. L. J. (I972a). Vet. Rec. 9I, 67.

Lawrence, T. L. J. (1972b). Vet. Rec. 91, 108.

Lawrence, T. L. J. (1972c). Cereal Processing \& Digestion p. 77. London: US Feed Grains Council.

Livingston, R. M., Denerley, H., Stewart, C. S. \& Elsley, F. W. H. (1971). Anim. Prod. x3, 547.

Livingston, R. M. \& Livingston, D. M. S. (1970). Anim. Prod. 12, 561.

McGinty, D. D. \& Riggs, J. K. (1968). F. Anim. Sci. 27, x 170.

McNeill, P., Potter, G. D. \& Riggs, J. K. (1971). J. Anim. Sci. 33, r 37 I.

Maxwell, C. V., Reimann, E. M., Hoekstra, W. G., Kowalczyk, T., Benevenga, N. J. \& Grummer, R. H. (1970). F. Anim. Sci. 30, 911.

Mudd, C. A. \& Perry, T. W. (1969). F. Anim. Sci. 28, 822.

Neuhaus, V. \& Totusek, R. (1971). F. Anim. Sci. 33, г32 1.

Nicholson, J. W. G., Gorrill, A. D. L. \& Burgess, P. L. (1971). Can. J. Anim. Sci. 51, 697.

Orskov, E. R. F., Fraser, C. \& Kay, R. N. B. (1969). Br. F. Nutr. 23, 2 I7.

Perez-Aleman, S., Dempster, D. G., English, P. R. \& Topps, J. H. (1971). Anim. Prod. 13, 27 I.

Pickford, J. R. (I968). In University of Nottingham : Nutrition Conference for Feed Manufacturers: No. 2 p. 175 [H. Swan and D. Lewis, editors]. London: J. \& A. Churchill Ltd.

Potter, G. D., McNeill, J. W. \& Riggs, J. K. (I971). F. Anim. Sci. 32, 540.

Reed, J. H. \& Kidder, D. E. (I970). Res. vet. Sci. x1, 438.

Riggs, J. K. \& McGinty, D. D. (1970). F. Anim. Sci. 31, 99 I.

Riker, J. T., Perry, T. W., Pickett, R. A. \& Curtin, T. M. (r967). J. Anim. Sci. 26, 73 I.

Sturgess, I. M. \& Reeves, R. (1972). The Potential Market for British Cereals. London: Home Grown Cereals Authority.

Vance, R. D., Preston, R. L., Klosterman, E. W. \& Cahill, V. R. (1972). F. Anim. Sci. 35, 598.

Vanschoubroek, F., Coucke, L. \& Van Spaendonck, R. (197r). Nutr. Abstr. Rev. 4r, I.

Vohra, P. (1972). In Cereal Processing \& Digestion p. 53. London: US Feed Grains Council.

Waldo, D. R., Smith, L. W., Cox, E. I., Weinland, B. J. \& Lucas, H. L. Jr (1971). Y. Dairy Sci. 54, 1465 .

Zimmerman, D. R. \& Wostmann, B. S. (1963). F. Nutr. 79, 318. 